\title{
Türkçe Öğretiminde Yaratıcı Drama Yöntemine Dayalı Okuduğunu Anlama Stratejilerinin Kullanımına ve Yönteme İlişkin Öğrenci Görüşleri
}

\author{
Fatma SUSAR KIRMIZI- \\ Pamukkale Üniversitesi
}

\begin{abstract}
Özet
Bu araştırmanın temel amacı, Türkçe dersinde, yaratıcı drama yöntemine dayalı okuduğunu anlama stratejilerinin kullanımına ve yönteme ilişkin öğrenci görüşlerinin belirlenmesidir. Çalışma, 2005-2006 Ĕgitim-Öğretim Yllı Bahar Döneminde, İzmir ilinin Buca ilçesinde, MEB'e bă̆ll bir ilköğretim okulunda gerçekleştirilmiştir. Uygulama, toplam 37 (19 klz, 18 erkek) öğrenci ile yedi hafta sürmüş̧ür. Veri toplama aracı olarak okuma sürecinin aşamalarına ilişkin ǚ̧ sorudan oluşan bir form kullanılmıştır. Çalışma öncesinde ve sonrasında uygulanan bu soru formuyla öğrencilerin, okuduğunu anlama stratejileri hakkında neler bildikleri ve bu stratejileri kullanıp kullanmadıkları değerlendirilmiştir. Ayrıca yapılan uygulama sonunda Yaratıcı Drama çalışmalarına ilişkin olarak da ögrencilerin görüşleri alınmıştır. Öğrencilerin uygulama öncesi ve uygulama sonrası verdiği yanıtlar incelendiğinde, okuduğunu anlama stratejilerini kullanmaya ilişkin görüşlerinin oldukça geliştiği ve zenginleştiği söylenebilir. Yaratıcı Drama etkinlikleri sayesinde öğrencilerin Türkçe dersine yönelik bakışlarında da olumlu yönde değişiklikler olmuştur.
\end{abstract}

Anahtar Sözcükler: Yaratıcı drama, okuduğunu anlama stratejileri, Türkçe ögrretimi, İlköğretim.

\begin{abstract}
With this study, basically, the purpose was to determine the effect of creative drama method in the process of reading comprehension education in scope of elementary school Turkish lesson, and students' opinions about the method. The study was carried out in a public elementary school in Bucaİzmir in the spring semester of 2005- 2006 academic year. The treatment implemented on 37 (19 female, 18 male) students and lasted seven weeks. The instrument was a scale with three questions about reading process. This scale was used as pre and post test and used to determine what students know about reading strategies and whether they used these strategies. At the end of the treatment, the students' opinion was gathered about Creative Drama activities. Examining the students responses on the pre and post test, it can be said that the opinions about reading strategies were developed and riched. The students' views to Turkish course were changed positively with the help of creative drama activities.
\end{abstract}

Keywords: Creative drama, reading strategies, Turkish teaching, Elementary Education 


\section{Giriş}

Yaratıcı drama grup etkinliğine dayalı bir çalışmadır. Sürecin oluşumu yaşantılar sonucu elde edilen bilgi ve deneyimin yeniden şekillenerek ortaya konulmasına dayalıdır. Olaylar o anda, kendiliğinden ve drama teknikleri kullanılarak sergilenir. "Yaratıcı Drama, doğaçlama, rol oynama vb. tiyatro ya da drama tekniklerinden yararlanılarak, bir grup çalışması içinde, bireylerin bir yaşantıyı, bir olayı, bir fikri, kimi zaman bir soyut kavramı ya da bir davranışı, eski bilişsel örüntülerin yeniden düzenlenmesi yoluyla ve gözlem, deneyim, duygu ve yaşantıların gözden geçirildiği “oyunsu” süreçlerde anlamlandırılması, canlandırılmasıdır. Ancak yaratıcı drama çalışmaları 1. Tiyatro yapmak değildir; 2. Oyunculuk değildir." (San, 1999: s.267; San, 2002a: s.81). Yaratıcı dramada önemli olan saptanan amaçlara göre işlenecek konunun uygun olan gruba, gereken zamanda verilirken tüm etkinlikler arasında bir bağlantının olması, etkinliklerin birbirini destekleyen ve bütünleyen bir özelliğe sahip olması ve katılımcıda içselleştirilmesi düşünülen kazanımlara ulaşmada etkili olup olmayacağının belirlenmesidir (Adıgüzel, 2006: s.25).

Okvuran'a göre (2002) tüm eğitim kademelerinde ve her yaştan insana uygulanabilecek yaratıcı drama çalışmaları eğitimin sıkıcı kalıplarını kırarak, çağdaş eğitim sistemiyle bütünleştirilebilir ve kendini geliştirme gereksinimi ve heyecanı duyan öğretmen ve öğrenciler yaratabilir. Yaratıcı drama'da bir konu ya da durum canlandırılır, yaşayarak yansıtılır, yaşantıya dönüştürülür. Böylece öğrenci, öğrenme sürecinde etkin durumdadır, kendi yaptığıyla öğrenirken bir yandan da duyu organlarını harekete geçirmekte olay ya da durumları yaşamaktadır (Üstündağ, 2000). Yaratıcı dramayla birey düşünür, plan yapar, organize eder ve düşüncesini eyleme dönüştürerek uygular. Bu süreçte de yaşantılar yoluyla yeni davranış ve duyguları öğrenir, deneyim sahibi olur. Böylece birey duygularını kontrol edebilme, değiştirebilme, düşüncelerini ifade edebilme, konuşarak iletişim kurabilme gibi yeteneklerini geliştirir (Vural, 2004: s.199). Moffett'e göre dramatik etkileşim, düşünme ve dil gelişiminin ilk aracıdır. Nixon'a göre; yaratıcı dramanın amaçları arasında bireyin yazılı ya da sözlü olarak kullandığı dilin sınırlarını genişletme ve dili etkili olarak kullanma bulunmaktadır (Akt: Üstündağ; 2002: s.245).

\section{Türkçe Öğretimi ve Yaratıcı Drama}

Yaratıcı drama, çocukların, dili sınıfta kullanmalarına firsat yarattığından dolayı, bunu daha geniş sosyal olaylarda kullanmalarını sağlamaktadır. Böylece konuşma dilinin gelişmesinde önemli bir rol oynar ve öğrenciler, dili çok çeşitli amaçlar için kullanılabilirler. Örneğin, ikna etme, iddia etme ve yatıştırma gibi. Rol oynama aynı zamanda çocukların grupla konuşmasını da gerektirir. Yaratıcı drama, çocukların içinde yaşadıkları sosyal dünyayı ve çevrelerindeki insanları, hatta diğer toplum insanlarını 
tarihi ve coğrafi yönden anlamalarında yardımcı olur. Bu nedenle dünyada olduğu kadar ülkemizde de dil eğitiminde yaratıcı drama yöntemine yer verilmeye başlanmıştır.

Türkçe Dersi (1- 5 sınıflar) Öğretim Programı Çağdaş yaklaşımlar doğrultusunda MEB Talim ve Terbiye Kurulu Başkanlığı'nca 12.07.2004 tarihinde kabul edilen bir kararla bir yıl pilot okullarda denendikten sonra birtakım düzenlemelerle 2005- 2006 eğitim- öğretim yılından itibaren bütün okullarda uygulamaya konulmuştur (MEB, 2006). Programda yaratıcı drama yönteminin yanı sıra Çoklu Zeka Kuramı, İşbirlikli Öğrenme, Yapılandırmacı Yaklaşım gibi bir çok yeni yaklaşım ve yönteme de yer verilmiştir.

\section{Okuduğunu Anlama Stratejileri}

İşlevsel bir okur kitlesi yaratmanın amacı, ülkenin insan gücünü aydınlatmak, bağımsız, başı dik, üretici ve ürettiğinin hakkını isteyen bir toplum yaratmaktır (Sarıhan, 2003: s.31). Okuma, çağdaş olmanın ölçütlerinden birisidir. Çağdaş, yaratıcı, yapıcı ve özgür düşünceye sahip, üretken, eleştirel bakan bireylerden oluşan bir toplum olmak, okuma bilinci aşılanmış bireylerle mümkündür. Çünkü toplumun gelişmeler ve değişmelere uyum sağlaması, bu bilincin sağlanması ile söz konusudur (Bircan ve Tekin, 1989: s.393). Ülkemizde, okuma düzeyinin düşük olduğu sürekli vurgulanır. Bu noktada ilginç bir paradoks söz konusudur. Okur yazar oranı arttıkça okuma düzeyi düşmektedir. Nitelikli bir okur yazar kitlesi yetiştirmek için iyi bir okuma eğitimi en önemli koşuldur. İyi bir okuma eğitimi de bunun sevdirilmesine bağlıdır.

Bilgi birikiminin temel amacı sayılan okuma, eğitim süreçlerinde ve toplumsal konularda bilgi kazanımının temel yollarından biridir. "Okuduğunu anlamak için kelimelerdeki anlamı basit bir şekilde yakalamak yeterli değildir. Etkili bir okuyucu anlayarak okumayı başarmak için, metinle kendi yaşantısını ilişkilendirebilme, bilgiyi özetleyebilme, sonuç çıkarma, metne yönelik sorular oluşturma gibi uygulamaları etkin bir şekilde yapabilmelidir" (Allen, 2003; Keer ve Verhaeghe, 2005). "Metnin, okuyucu tarafından anlaşılması biliş ve bilişüstü stratejilerin etkili bir şekilde kullanılmasına bağlıdır" (Allen, 2003; Harvey ve Anne 2002; Schunk ve Zimmerman, 1994). Etkili okuyucular, bir metni anlamayı kolaylaştıran okuduğunu anlama stratejilerini ustalıkla kullanır.

Son yıllarda yapılan araştırmalar etkili ve iyi okuyucuların etkin bir şekilde okuyabilmek ve bunu sürdürebilmek için okuma öncesinde, okuma sırasında ve okuma sonrasında birtakım zihinsel etkinlikler kullanarak "yapılandırmacı bir süreç” geçirdiğini ortaya koymaktadır (Allen, 2003). Bunlara okuduğunu anlama stratejileri denilmektedir. Okuduğunu anlama stratejileri genel olarak alan yazında 3 grupta toplanmıştır. Bunlar:

1.Okuma Öncesi Stratejiler 
2.Okuma Sırası Stratejiler (Anlamı Yapılandırma Stratejileri)

3.Okuma Sonrası Stratejilerdir (Düzeltme ve Anlamlandırma Stratejileri) [1].

Tablo 1 Okuma Öncesinde, Okuma Strasında ve Okuma Sonrasında Okuduğunu Anlama Stratejileri

\begin{tabular}{ll}
\hline $\begin{array}{l}\text { Okuma Sürecini Oluşturan } \\
\text { Aşamalar }\end{array}$ & \multicolumn{1}{c}{$\begin{array}{c}\text { Okuma Sürecinin Aşamalarına İlişkin } \\
\text { Stratejiler }\end{array}$} \\
\hline Oközden Geçirme/İnceleme \\
Okuma Amaçlarını Belirleme \\
Önbilgileri Harekete Geçirme \\
Sorular Çıkarma \\
Tahminde Bulunma/Hipotez Oluşturma \\
\hline $\begin{array}{l}\text { Okuma Sırasında Stratejiler } \\
\text { (Anlamı Yapılandırma }\end{array}$ & İlişki Kurma \\
Stratejileri) & Zihninde Canlandırma Tanımlama \\
& Sorulara Yanıt Arama ve Yeni Sorular Oluşturma \\
& Hedefe Odaklanma \\
& Tahminleri/Hipotezleri Kontrol Etme \\
& Not Alma \\
& Karmaşık Noktaları Belirleme \\
& Akıcı Okuma \\
\hline $\begin{array}{l}\text { Okuma Sonrası Stratejiler } \\
\text { Stratejileri) }\end{array}$ & Özetleme \\
& Soruları Yanıtlama \\
& Sentez Yapma \\
& Metni Görsel Ögelerle İfade Etme \\
& Değerlendirme \\
\hline
\end{tabular}

(Susar-Kırmız1, 2006: s.27)

Lukenbill (2004), strateji eğitimi sayesinde öğrencilerin öğrenmeyi daha başarılı bir şekilde gerçekleştirebileceğini, öğrendikleri ve gerçek dünya arasında daha kolay bir ilişki kurabileceklerini ifade etmektedir.

Öğrencilerin anlamlı okumayı başarabilmesi için planlı programlı bir strateji eğitimine ihtiyaçları vardır. Onlar, hangi stratejiyi nerede, ne zaman, nasıl ve niçin kullanacaklarını bilmelidir (Belk, Seed ve Abdi, 2005; Rhoder, 2002). Strateji eğitiminde öğrencinin zevk alacağı ve onu etkin k1lacak yöntemlere yer verilmesi okuma stratejilerinin kullanımını ve dil eğitimini olumlu yönde etkilemektedir (Lin, 1999; Keer ve Verhaeghe, 2005). Yaratıcı drama da bu yöntemlerden birisidir. Yaratıcı drama yöntemine ilişkin olarak son yıllarda birçok çalışma yapılmıştır. Bunlardan bazıları aşağıda verilmektedir. 
Lin (1999) Tayvan'da farklı etnik kökenlerden gelen öğrencilerle yaratıcı drama ve hikaye çalışması yapmıştır. Çalışmanın amacı öykünün anlaşılmasında yaratıcı drama yönteminin, grup tartışması ve hikayenin sesli bir şekilde tekrarlanması teknikleriyle karşılaştırılmasıdır. Çalışma yaratıcı drama grubu, tartışma grubu ve yüksek sesle tekrarlama gruplarıyla yürütülmüştür. Beş altı yaş grubuyla yapılan uygulama, yedi hafta sürmüştür. Araştırma ile ilgili veriler öykü anlatımından, resim çalışmalarından ve on maddelik görüşme sorularından elde edilmiştir. Çalışmanın sonucuna göre; öğrenciler, öyküler canlandırıldığında ve benzetmeler yapıldığında daha iyi performans göstermiştir.

Ataman (2006), yaratıcı drama yöntemine ilişkin yaptığı çalışmasında, yazınsal değeri olan ürünler ortaya çıkarmayı ve öğrencilerin yazmaya karşı istek duymasını amaçlamıştır. Araştırma, Bilkent Üniversitesi Hazırlık Okulu, 4. sınıf öğrencileriyle gerçekleştirilmiştir. Çalışma tek bir sözcükten (bavul) yola çıkılarak kurgulanmış ve yazılı anlatım çalışmaları bu sözcük etrafında şekillendirilmiştir. Yazılı anlatım çalışmaları öncesi, yaratıcı drama uygulamaları yapılarak, öğrencilerin yazacaklarını düşlemeleri, oynamaları ve canlandırmaları sağlanmıştır. Bu çalışmada yaratıcı drama, yöntem olarak kullanılmıştır. Yazım öncesi yaratıcı drama uygulamalarında, şiir, öykü ve masallardan yararlanılmıştır. Her atölye sonrası, öğrenciler yazınsal değeri olan ürünler ortaya koymuşlardır. Yaratıcı drama yöntem olarak kullanıldığında, Türkçe dersinin yazma kazanımları verilirken etkili olduğu, yazınsal değeri olan ürünler ortaya çıkmasında yarar sağladığı, öğrencilerin yazılı anlatım çalışmalarına istekle katıldığı sonucuna varılmıştır.

\section{Araştırmanın Amacı ve Önemi}

Bu araştırmanın temel amacı, İlköğretim 4. sınıf Türkçe dersi kapsamında, yaratıcı drama yöntemine dayalı okuduğunu anlama stratejilerinin kullanımına ve yaratıcı drama yöntemine ilişkin öğrenci görüşlerini belirlemektir.

Okuduğunu anlama stratejilerinin kullanımı öğrencinin kendi kendine öğrenmesini, okuduğu üzerinde düşünmesini, bilgiyi zihninde yapılandırmasını sağlayan önemli bir süreçtir. Bu bağlamda yaratıcı drama ve okuduğunu anlama stratejilerinin eğitim ve öğretimde bir araya getirilmesinin iyi bir deneyim olacağı, öğrenmede önemli firsatlar sağlayacağı, eğitim sürecini oldukça etkili kılacağı düşüncesi ile çalışmanın konusu belirlenmiştir.

Strateji eğitimi ve yaratıcı dramanın bir araya getirilmesiyle ortaya konulan öğretimsel işlerde sınıftaki her öğrenen, grup arkadaşlarıyla birlikte derse katılarak; metnin ana fikrini bulma, bulduğu ana fikre ilişkin şarkı sözü yazma, resim çizme, canlandırma, posterler oluşturma ve bunlar gibi pek çok etkinlikler yapar. Bunları yaparken de öğrenci, yönteme uygun olarak, grup arkadaşlarıyla konuşur, tartışır, düşünce alışverişinde bulunur, ortak bir sonuca ulaşmaya çalışır ve hep birlikte bir ürün ortaya 
çıkarır. Böylece Türkçe Öğretiminde hayat boyu ve severek okuma alışkanlığı geliştirebilme olanağ1 yakalanmış olur.

$\mathrm{Bu}$ araştırmada, okuduğunu anlama stratejilerinin kullanımına yönelik olarak yaratıcı drama yöntemi temel alınmış, öğrencilerin uygulama süreci öncesi ve sonrası okuduğunu anlama stratejilerinin kullanımına ilişkin görüşleri tespit edilmiştir.

\section{Yöntem}

$\mathrm{Bu}$ araştırma, yaratıcı drama yöntemine dayalı okuduğunu anlama stratejilerinin kullanımına ve yönteme ilişkin öğrenci görüş ve düşüncelerini belirlemeye yönelik bir çalışma olduğundan nitel araştırma yöntemi kullanılmıştır.

\section{Çalışma Grubu}

Araştırmanın orta sosyo-ekonomik düzeydeki bir okulda gerçekleştirilmesi planlandığından öncelikle, İzmir Milli Eğitim Müdürlüğü’nden Buca ilçesinde yer alan ilköğretim okullarının isimleri alınmıştır. $\mathrm{Bu}$ okullar bulunduğu semtlerin sosyal ve ekonomik oluşumuna göre alt, orta ve üst olmak üzere üç tabaka halinde gruplandırılmıştır. Orta tabakada yer alan okullardan birisi seçkisiz yöntemle tespit edilmiş, ayrıca okulun yöneticileriyle de konuya ilişkin görüşme yapılmıştır. Okulun orta sosyoekonomik düzeyde olduğu düşüncesine ulaşıldıktan sonra, araştırmanın bu okulda yapılmasına ilişkin gerekli izin İzmir Milli Eğitim Müdürlüğünden alınmıştır. Çalışma, 2005-2006 eğitim-öğretim yılının ikinci (bahar) döneminde, İzmir ilinin Buca ilçesinde, ilköğretim 4. sınıf öğrencileri ile gerçekleştirilmiştir. Toplam 37 (19 kız, 18 erkek) öğrenci ile "Yenilikler ve Gelişmeler" temas1 kapsamında yürütülen çalışma, yedi hafta sürmüştür. Tema içerisinde şu konular yer almaktadır:1. Haberleşme 2. Çocuklar Doğuştan Bilim Adamıdır 3. Hayalimdeki Robot 4. Teknolojinin Hayatımızdaki Yeri 5. Uzaya Giden Uçurtma.

\section{Veri Toplama Aracı}

Veri toplama aracı olarak, okuma sürecinin aşamalarına ilişkin üç sorudan oluşan bir form hazırlanmıştır. Forma ilişkin olarak alanında uzman beş öğretim elemanı ve iki sınıf öğretmeninden uzman görüşü alınmıştır. Form, çalışma öncesi ve çalışma sonrası olmak üzere iki defa öğrencilere uygulanmıştır. Çalışma öncesinde uygulanan bu soru formuyla öğrencilerin, okuduğunu anlama stratejileri hakkında neler bildikleri ve bu stratejileri kullanıp kullanmadıkları değerlendirilmek istenmiştir. Uygulama öncesinde öğrencilere üç sorudan oluşan form uygulanmış, daha sonra bu formlara ayrı ayrı numaralar verilmiştir. Numaralandırılmış formlarda yer alan öğrenci görüşleri bilgisayar ortamına aktarılmıştır. Veriler birkaç kez satır satır okunmuş, her bir öğrencinin okuduğunu anlama stratejilerinin kullanımına ilişkin görüşleri tespit edilmiştir. Güvenirlik çalışması için öğrenci 
görüşlerine yönelik tespitin tekrarlanmasında başka bir öğretim üyesinden yardım alınmıştır. Araştırmacı ve diğer öğretim üyesinin yaptığı tespitler karşılaştırılarak soruların güvenirliği “Güvenirlik=Görüş Birliği/Görüş Ayrılığ $1+$ Görüş Birliği x 100” formülü ile hesaplanmıştır. Güvenirlik katsayısı, birinci soru için \% 81,37, ikinci soru için \% 79,18, üçüncü soru için \% 73,46, olarak bulunmuştur.

Aynı form çalışma sonunda, öğrencilere tekrar uygulanarak okuduğunu anlama stratejilerinin kullanımında hangi değişikliklerin gerçekleştiği değerlendirilmiştir. Uygulama öncesinde güvenirlik çalışması için izlenen süreç aynen tekrar edilmiş. Her bir soru için güvenirlik çalışması yapılmıştır. Güvenirlik formülü ile elde edilen sonuçlara göre birinci sorunun güvenirlik katsayısı 79,40, ikinci sorunun güvenirlik katsayısı 76,28, üçüncü sorunun güvenirlik katsayısı ise 81,67 'dir. Uygulama öncesi ve sonrasında belirlenen öğrenci görüşleri araştırmanın amacına uygun bir şekilde ortaya konulmuş ve bu görüşlerden yola çıkılarak yorumlar yapılmıştır. Araştırmacı tarafından yapılan yorumların desteklenmesi açısından bu görüşlerden bazı örnekler ve formda yer alan sorular tablolar halinde sunulmuştur.

Ayrıca öğrencilere, yedi hafta boyunca yapılan yaratıcı drama çalışmalarına ilişkin düşünceleri sorulmuştur. "Yaptığınız yaratıcı drama çalışmalarıyla ilgili olarak neler düşünüyorsunuz?" şeklinde oluşturulan tek bir soruya öğrencilerin yanıt görüşlerini yazmaları istenmiştir. Öğrencilerin yazılarına numaralar verilerek, elde edilen veriler bilgisayar ortamına aktarılmıştır. Yönteme ilişkin önemli olduğu düşünülen görüşler araştırmacı tarafından belirlenmiş, güvenirlik çalışması için öğrenci görüşlerine yönelik tespitin tekrarlanmasında yine başka bir öğretim üyesinden yardım alınmıştır. Araştırmacı ve öğretim üyesinin görüşlerinin tutarlılığı daha önce belirtilen güvenirlik formülü ile hesaplanmıştır. Yapılan bu hesaplama sonunda güvenirlik katsayısı 75,22 olarak tespit edilmiştir. Yönteme ilişkin belirlenen öğrenci görüşleri de aynı şekilde araştırmacı tarafından yorumlanmış, yapılan yorumun desteklenmesi açısından öğrenci görüşlerinden bazıları tablo halinde sunulmuştur.

\section{İşlem}

Çalışmaya başlamadan önce, okuduğunu anlamaya ilişkin kazanımlar belirlenmiştir. Daha sonra bu kazanımlar doğrultusunda 2005-2006 Türkçe Dersi Öğretim Programında yer alan "Yenilikler ve Gelişmeler" temasında yer alan metinlerden yola çıkılarak etkinlikler düzenlenmiştir. Eğitim programının oluşturulması sürecinde yirmi dört ayrı kazanım belirlenmiş, kazanımların gerçekleşmesinde yardımcı olacak Türkçe metinler seçilmiştir. Kazanımlar ve metinlerden yola çıkılarak yapılacak olan çalışmalar ve etkinlikler planlanmıştır. Bu etkinlikler hazırlanırken yaratıcı drama yöntemi temel alınmıştır. 
Araştırmacı tarafindan planlanan ve yürütülen çalışma, haftada beş ders saati olmak üzere, yedi haftada gerçekleştirilmiştir. Uygulama süreci içerisinde Türkçe eğitiminin unsurları olan dinleme, konuşma, okuma, yazma, görsel okuma ve görsel sunu becerilerinin bir bütün olduğu ilkesinden hareket edilmiş, günlük planlar ve çalışma yaprakları bu anlayış içerisinde hazırlanmıştır. Ancak okuduğunu anlama etkinliklerine ayrı önem verilmiştir. Çalışmalar, okulun yaratıcı drama derslerinin yürütüldüğü geniş bir salonda yapılmıştır. Yaratıcı drama çalışmalarında denge çalışmaları, fotoğraf kullanma, istasyon tekniği, doğaçlama, resim yapma, cıbırış, ritim, öykü yazma, devinim tiyatrosu, donuk imgeler, şiiri masallaştırma, maske çalışması, televizyon programı yapma, bilinç koridoru gibi teknik ve etkinliklere yer verilmiştir. Etkinliklerin gerçekleştirilmesinde hikaye haritası, resim çizme, $5 \mathrm{~N} 1 \mathrm{~K}$, başlık bulma, metnin içeriğini tahmin etme, duvar gazetesi hazırlama, paragraf tamamlama, şarkı sözü yazma, ritim tutma, özetleme, resim yapma gibi çalışmalar grup ürünü olarak istenmiştir. Ders sonlarında etkinlik süreci farklı şekillerde değerlendirilmiştir. Sözü edilen çalışmaların planlanması ve uygulanması yaratıcı drama için liderlik eğitimi almış olan araştırmacı tarafından gerçekleştirilmiştir. Yaratıcı drama etkinlikleri şu aşamalar esas alınarak hazırlanmış ve uygulanmıştır: 1. Hazırlık-Isınma Çalışmaları 2. Canlandırma 3. Değerlendirme-Tartışma (Adıgüzel, 2002; Adıgüzel, 2006). Yapılan uygulamalara yönelik olarak hazırlanan planlardan birisi EK-1'de sunulmaktadır.

\section{Bulgular ve Yorum}

$\mathrm{Bu}$ bölümde, çalışma grubunun uygulama öncesi ve sonrası uygulanan soru formuna verdikleri yanıtlara; ayrıca çalışma sonunda öğrencilerin yaratıcı dramaya ilişkin düşüncelerine ve bunların değerlendirmelerine yer verilmiştir.

\section{Soruya İlişkin Bulgular ve Yorum}

Öğrencilere verilen soru formunda yer alan birinci soru "Bir metni okumadan önce metni daha iyi anlamak için neler yaparsınız?" şeklinde oluşturulmuştur. Oluşturulan bu soruda öğrencilerin düşüncelerine göre okuma öncesi stratejilerin kullanımı ortaya konulmak istenmiştir. Öğrencilerin çalışma öncesi ve sonrasında bu soruya verdikleri yanıtlar özet olarak Tablo 2'de yer almaktadır. 
Tablo 2 Öğrencilerin Çalışma Öncesinde ve Çalışma Sonrasında Birinci Soruya Verdiği Yanıtlar

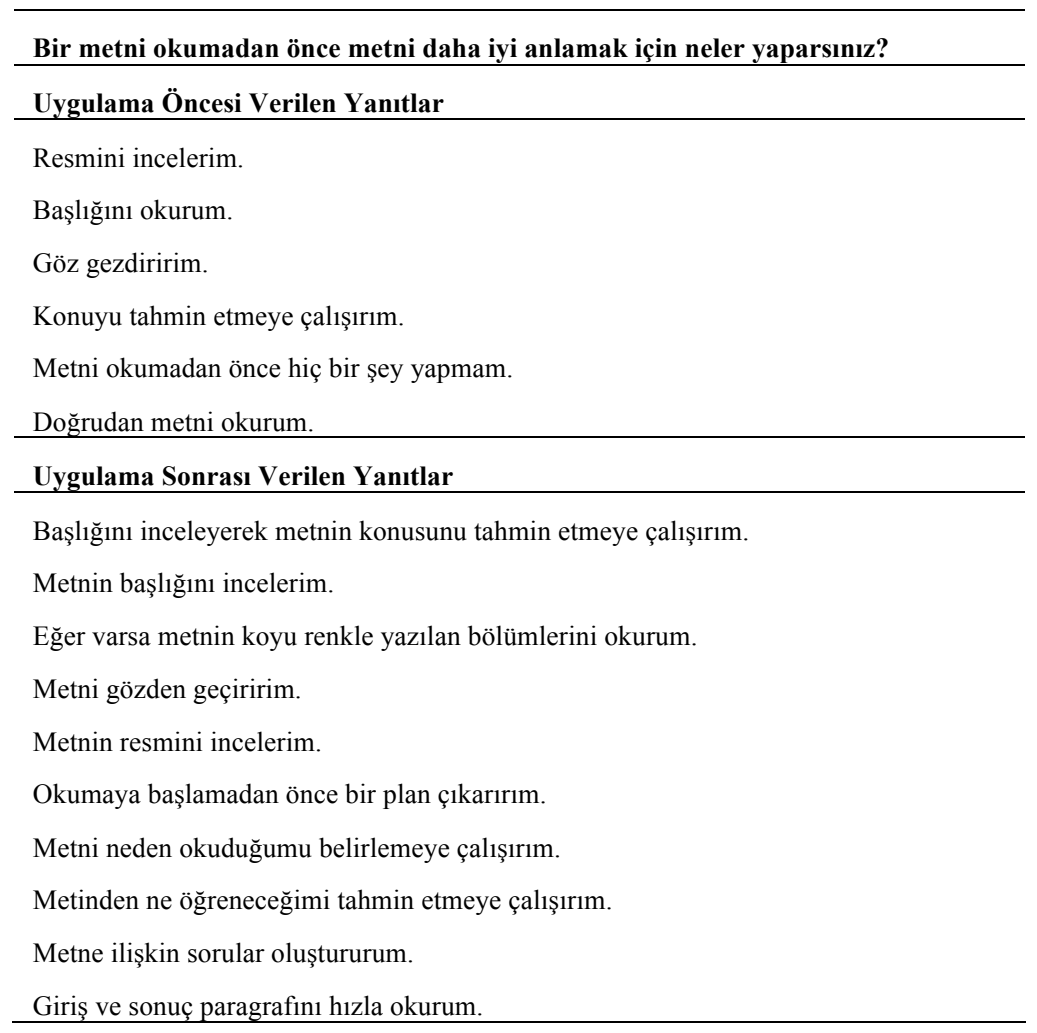

Öğrencilerin uygulama öncesi ve uygulama sonrası verdiği yanıtlar incelendiğinde okuma öncesi stratejileri kullanmaya ilişkin görüşlerinin oldukça farklılaştığı ve zenginleştiği söylenebilir. Uygulama öncesi yanıtlar incelendiğinde okuma öncesi stratejilerin kullanımına ilişkin olarak öğrencilerin daha yüzeysel bilgilere sahip olduğu, bu stratejilerin bir çoğunu bilmedikleri ve kullanmadıkları söylenebilir. Ancak uygulama sonrasında verilen yanıtlar bu durumun büyük oranda değiştiğini göstermektedir.

\section{Soruya İlişkin Bulgular ve Yorum}

Öğrencilere uygulanan formda yer alan ikinci soru okuma sırası stratejileri (Anlamı Yapılandırma Stratejileri) değerlendirmeye yönelik olarak "Bir metni okuma esnasında metni daha iyi anlamak için neler yaparsınız?” şeklinde belirlenmiştir. Yöneltilen bu soru ile öğrencilerin okuma sırası stratejileri kullanma durumlarına ilişkin düşünceleri, uygulama öncesi ve uygulama sonrasına göre değerlendirilmek istenmiştir. Öğrencilerin çalışma öncesi ve sonrasında verdikleri yanıtlar özet olarak Tablo 3'te yer almaktadır.

Tablo 3. Öğrencilerin Çalışma Öncesinde ve Çalışma Sonrasında İkinci Soruya Verdiği Yanıtlar 


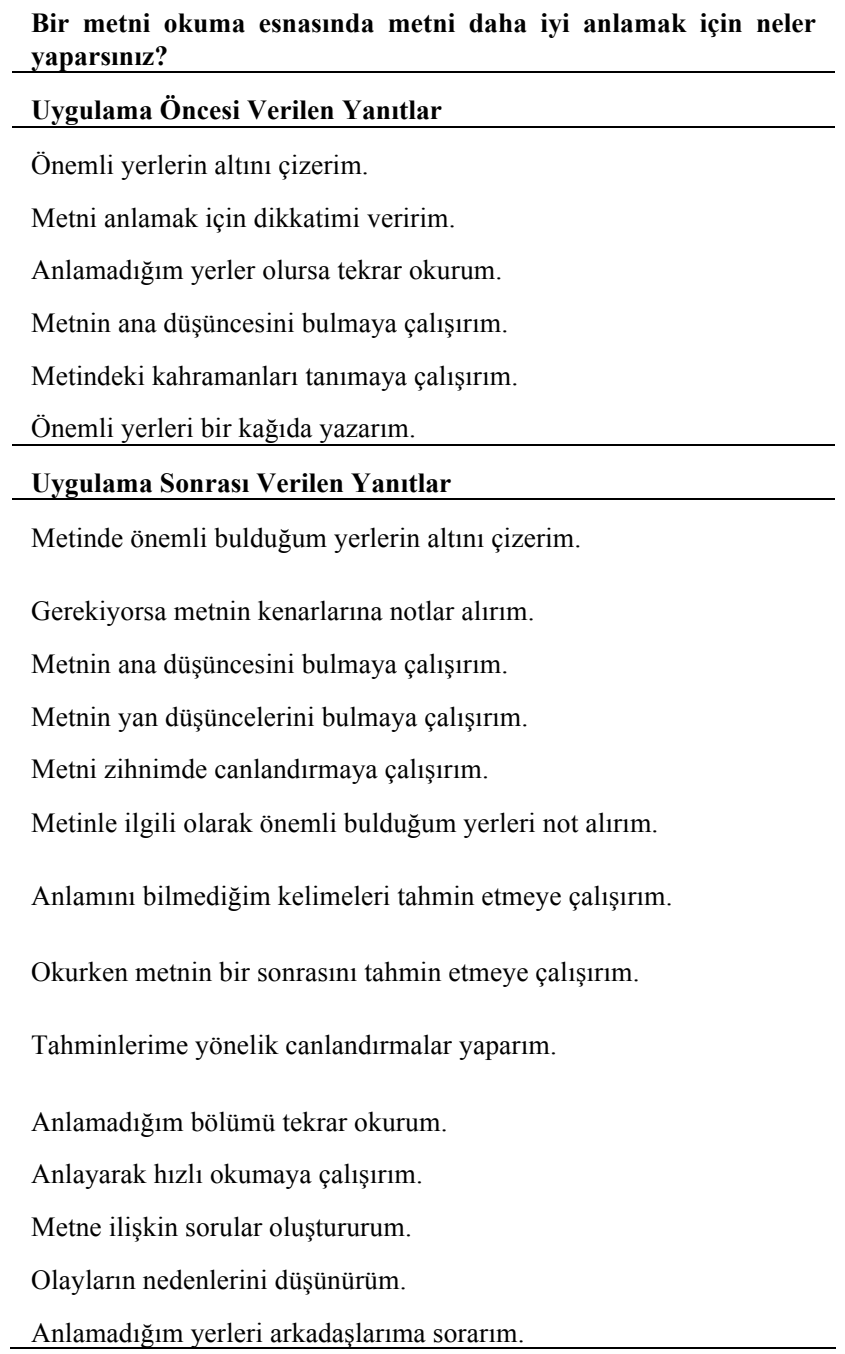

Okuma sırası stratejilerin kullanımına ilişkin olarak verilen yanıtlar incelendiğinde uygulama sonrasında öğrencilerin düşüncelerinde önemli ölçüde farklılıklar oldu söylenebilir. Uygulama öncesi yanıtlar incelendiğinde okuma sırasında, öğrencilerin kullandıkları stratejilerin oldukça sınırlı olduğu görülmektedir. Uygulama sürecinin bu konuda önemli değişiklikler yarattığı ifade edilebilir.

\section{Soruya İlişkin Bulgular ve Yorum}

Öğrencilere uygulanan formda yer alan üçüncü soru okuma sonrası stratejilerin (Düzeltme ve Anlamlandırma Stratejileri) kullanımına yönelik düşünceleri belirlemek için oluşturulmuştur. "Metni okuduktan sonra metni daha iyi anlamak için neler yaparsınız?" şeklinde belirlenen soruya, uygulama öncesi ve uygulama sonrası verilen yanıtlar Tablo 4'te sunulmaktadır. 
Tablo 4 Öğrencilerin Çalışma Öncesinde ve Çalışma Sonrasında Üçüncü Soruya Verdiği Yanıtlar

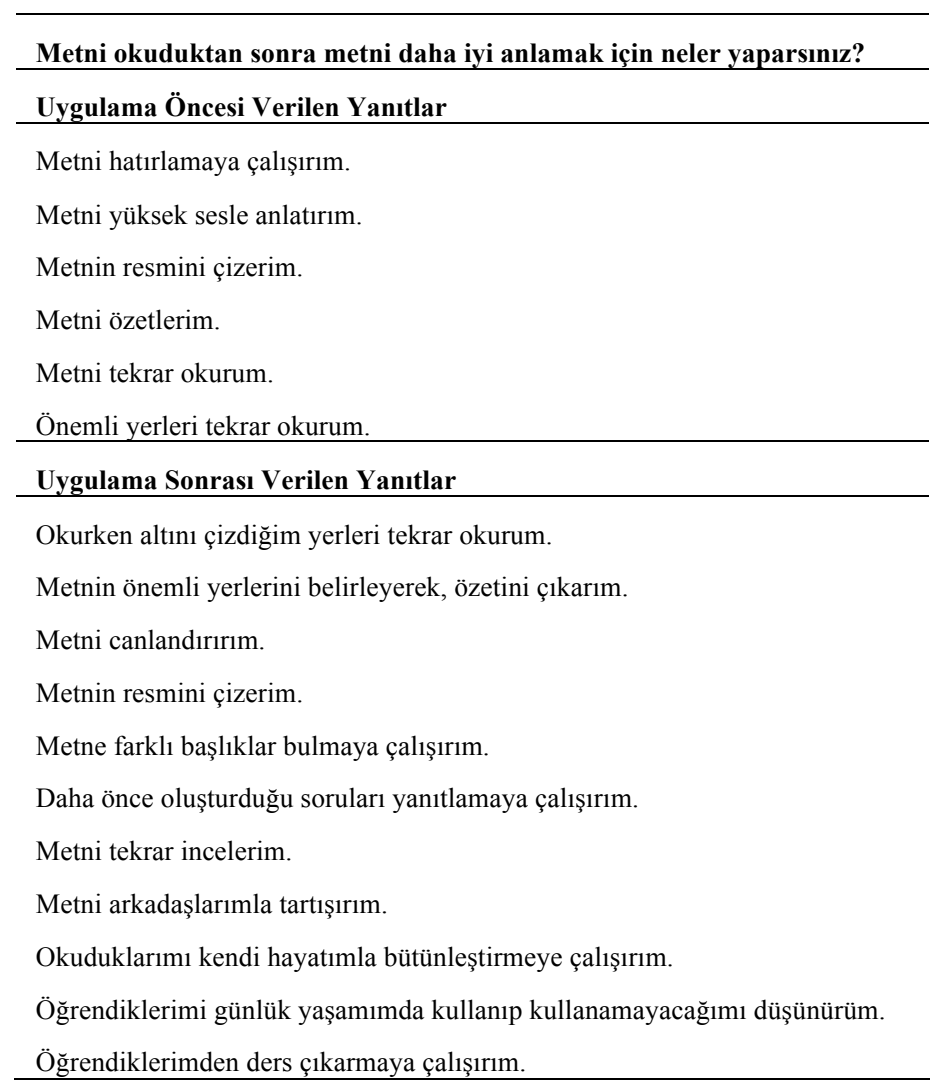

Okuma sonrası stratejilerin kullanımına ilişkin olarak, deneklerin düşünceleri incelendiğinde uygulama sonrasında önemli gelişmeler olduğu söylenebilir. Bu stratejilerin kullanımı daha da zenginleşmiştir. Ayrıca her üç soruya verilen yanıtlar incelendiğinde öğrencilerin anlatma ve yazma becerilerinde de önemli gelişmeler olduğu söylenebilir. Daha öncede belirtildiği gibi düzenlenen etkinlikler, Türkçe öğretiminin ilkelerine uygun olarak tüm beceri alanlarını kapsayacak şekilde hazırlanmıştır. Bu noktada, yaratıcı dramanın yalnızca okuduğunu anlama çalışmaları kapsamında değil, Türkçe Öğretiminin bütün beceri alanlarında etkin bir şekilde kullanılabileceği belirtilebilir.

\section{Katılımcıların Yaratıcı Drama Yöntemine İlişsin Düşünceleri}

Uygulama sonunda öğrencilere yaratıcı drama yöntemiyle yaptıkları çalışmalara ilişkin düşüncelerinin neler olduğu sorulmuş yanıtlarını yazmaları istenmiştir. Öğrencilerin verdiği yanıtlardan bazıları Tablo 5'te sunulmaktadır. 
Tablo 5 Öğrencilerin Yapılan Yaratıcı Drama Etkinliklerine İlişkin Düşünceleri

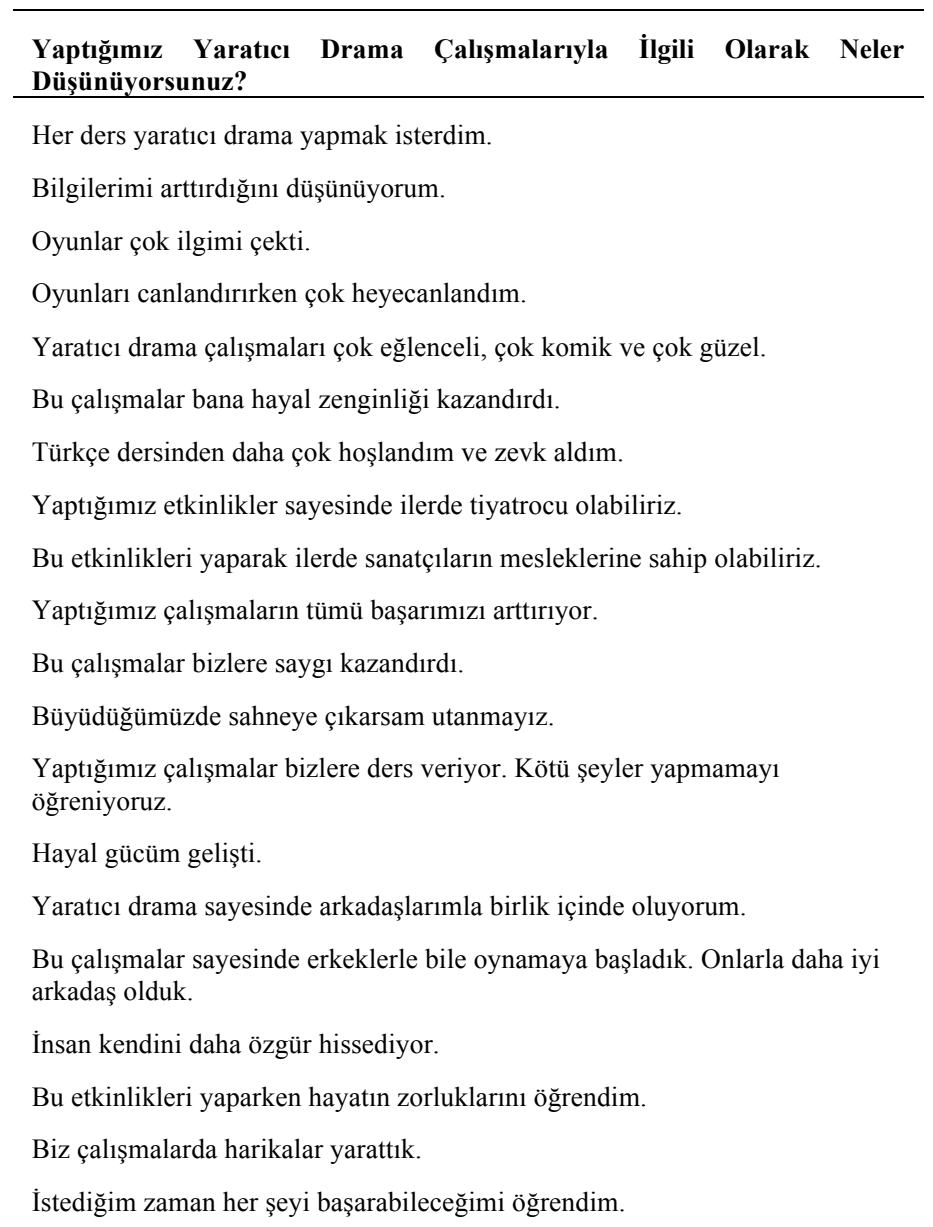

Öğrencilerin uygulama sonrasında, yaratıcı drama yöntemine ilişkin düşünceleri incelendiğinde, genel olarak olumlu ifadeler olduğu görülmektedir. Yaratıcı drama etkinlikleri, öğrencilerin Türkçe dersine kapsamında yapılan çalışmalara farklı bir bakış açısı ile bakmalarını sağlamıştır. Oyunlar, canlandırmalar, hayal gücünü geliştirici etkinliklerle sürdürülen Türkçe dersi öğrenciler için daha zengin bir anlam oluşturmuştur. Görüşler incelendiğinde, yaratıcı drama yönteminin yalnızca Türkçe dersi sürecine değil, öğrencilerin arkadaşlarıyla olan ilişkilerine ve kendilerine ilişkin içsel değerlendirmelerine de özgün bir bakış açısı kattığı söylenebilir. X

\section{Sonuç ve Tartışma}

Okuma, buna bağlı olarak okuduğunu anlama eğitim sürecinde ve toplumsal konularla ilgili bilginin kazanılmasında, öğrenmenin temellerinden biri olarak karşımıza çıkmaktadır. Öğrenen eğer etkin bir okuyucu değilse, öğrenmenin gerektirdiği zihinsel sürecin gerçekleştirilmesinde bir çok sorunla 
karşılaşacaktır. Çünkü okuma özellikle de anlayarak okumada görmenin ötesinde bir takım zihinsel etkinlikler gereklidir.

Öğrenciler zaman zaman çok çalışmalarına rağmen öğrenememekten ya da okuduğunu anlayamamaktan yakınmaktadır. Bu sorunların kaynağında temel olarak, nasıl öğreneceğini bilmeme durumu yer almaktadır. Son yıllarda yapılan çalışmalar ise öğrenenin kendi öğrenmesini düzenlemesinin ve kendi öğrenme sürecine etkin katılımının gerek anlayarak okumada gerekse öğrenmenin gerçekleşmesinde önemli etkileri olduğu noktasında birleşmiştir. Bir çok eğitimci öğrenmenin zihinsel bir süreç, öğretmenin ise yalnızca öğrencinin öğrenmesini kolaylaştıran unsurları işe koşmakla yükümlü olduğunu ortaya koymuştur. Öğrenmenin gerçekleşmesinin de öğrencinin çaba ve isteğiyle mümkün olduğu savunulmaktadır (Allen, 2003; Senemoğlu, 2001). Bu noktada öğrenme stratejilerinin ve bu stratejilerin etkili bir şekilde kullanımı büyük bir önem kazanmaktadır.

Etkin okumanın gerçekleşmesi okuduğunu anlama stratejilerinin başarılı bir şekilde kullanılmasına bağlıdır. İyi bir okuyucu yalnızca kelimeleri basit bir şekilde okumakla yetinmez (Susar-Kırmızı, 2004: s.37). Okumayı başarmak için, metne ilişkin tahminlerde bulunur, neden-sonuç ilişkileri kurar, metni gözünde canlandırır, önemli bulduğu yerlerin altını çizer, metne ilişkin notlar çıkarır, okuduklarıyla önceki bildiklerinin ilişkilendirir, adeta metnin içine girerek onun bir parçası olur ve böylece kendi zihninde yapılandırıcı bir süreç gerçekleştirir. Bu uygulamaları doğru bir şekilde yapabilen okuyucu anlayarak okumayı başardığı gibi, üst düzey düşünebilme becerisini de geliştirmiş olur. Okuduğunu anlama etkinliklerinin, yaratıcı drama yöntemiyle desteklenmesi sürecin aktif bir şekilde yaşanmasını sağlar. "Yaratıcı drama ile edinilen bilgilenme de okul disiplinleri içinde edinilen ezbere dayalı, kuramsal bilgilenme değildir. Yaratıcı dramada gene çeşitli disiplinlerden gelen bilgi kullanılır ama bu kez bilgiler ünik bir biçimde dünya ile kurulan öznel ve nesnel ilişkiler içinde yapılanır” (San, 2002b: s.69).

Strateji eğitiminin ve yaratıcı drama yönteminin bütünleştirilmesiyle ortaya konulan öğretimsel işlerde sınıftaki her öğrenci, grup arkadaşlarıyla birlikte öğrenme sürecine aktif bir şekilde katılmakta; metne yönelik tahminlerde bulunma, öykünün resmini çizme, ana fikirden yola çıkarak şiir yazma, raporlar oluşturma, metnin sonuçlarına ilişkin nedenleri ya da nedenlerine ilişkin sonuçları ortaya koyma, metni canlandırma, posterler oluşturma, fotoğraf karesi oluşturma ve bunlar gibi pek çok etkinlik yapmaktadır. Bunları yaparken de grup arkadaşlarıyla konuşmakta, tartışmakta, eleştirmekte, eleştirilmekte, fikir alışverişinde bulunmakta, ortak bir sonuca ulaşmaya çalışmakta, kısacası, yaratıcı drama yönteminin gereğini yapmaktadır. Araştırma süresince bu anlayış içerisinde hazırlanan ve uygulanan öğrenme etkinlikleri öğrencilerin öğrenme stratejilerini kullanmadaki başarısını arttırmıştır. 
$\mathrm{Bu}$ çalışmada da Türkçe dersinde, okuduğunu anlama stratejilerinin eğitiminde, yaratıcı drama yöntemi temel alınarak etkinlikler düzenlenmiş ve uygulanmıştır. Sınıf içi gözlemlerden, katılımcıların sorulara verdiği yanıtlardan çalışmanın belirlenen amaçlara ulaştığı söylenebilir. Okuma öncesi, sırası ve sonras1 stratejilerin kullanımına ilişkin olarak, deneklerin düşünceleri incelendiğinde uygulama sonrasında önemli gelişmeler olduğu söylenebilir. Okuduğunu anlama stratejilerinin kullanımı daha da zenginleşmiştir.

Ayrıca öğrencilerin, sorulara verdiği yanıtlar incelendiğinde, öğrencilerin anlatma ve yazma becerilerinde de önemli gelişmeler olduğu belirtilebilir. Çünkü her ne kadar araştırma, okuduğunu anlama çalışmalarını değerlendirmeye yönelik olsa da düzenlenen etkinlikler Türkçe öğretiminin ilkelerine uygun olarak tüm beceri alanlarını kapsayacak şekilde hazırlanmıştır ve öğrencilerin bütün dil becerileri geliştirilebilmiştir. Bu noktada, yaratıcı dramanın yalnızca okuduğunu anlama çalışmaları kapsamında değil, Türkçe Öğretiminin bütün beceri alanlarında etkin bir şekilde kullanılabileceği belirtilebilir.

Araştırma sonuçları doğrultusunda şu öneriler geliştirilmiştir: Eğitim Süreci içerisinde yaratıcı drama yöntemi okuduğunu anlama stratejilerinin eğitiminde etkin bir şekilde kullanılmalıdır. Yaratıcı drama yöntemine dayalı hazırlanan bu çalışma süresince öğrencilerin zaman zaman yönergeleri anlamakta zorlandığı araştırmacı tarafından tespit edilmiştir. Bundan sonra yapılacak araştırmalarda, etkinliklere yönelik hazırlanan yönergelerin daha ayrıntılı yazılması uygulayıcıların işini kolaylaştırabilir. Yalnızca okuduğunu anlama çalışmalarında değil Türkçe Öğretiminin bütün beceri alanları olan dinleme, konuşma, yazma, görsel okuma ve görsel sunu ile ilgili çalışmalarda da yaratıcı drama yöntemi kullanılmalı, bunlara yönelik ayrıntılı araştırmalar yapılmalıdır.

\section{Kaynaklar}

Adıgüzel, H.Ö. (2002). Eğitimde Yeni bir Yöntem ve Disiplin: Yaratıcı Drama. Yaratıcı Drama 19851995 Yazılar (Ed: H.Ö. Adıgüzel). Ankara: Natürel Kitap Yayıncılık.

Adıgüzel, H.Ö. (2006). Yaratıcı drama kavramı, bileşenleri ve aşamaları. Yaratıcı Drama Dergisi, 1(1), $17-29$.

Allen, S. (2003). An analitic comparison of three models of reading strategy instruction. Internal Review of Applied Linguistics in Language Teaching (IRAL), 41(4), 319.

Ataman, M. (2006). Yaratıcı drama sürecinde yaratıcı yazma. Yaratıcı Drama Dergisi, 1(1), 74-83. 
Belk, E. J., Seed, A.H. ve Abdi W. (2005). Content reading strategies. Science scope. ProQuest Education Journals, 28(6), 44.

Bircan, İ. ve Tekin, M. (1989). Türkiye'de okuma alışkanlığının azalması sorunu ve çözüm yolları. Ankara Üniversitesi Ĕ̆itim Bilimleri Fakültesi Dergisi, 22(1), 393-410.

Harvey, S. ve Anne, G. (2002). Strategies That Work: Teaching Comprehension to EnhanceUnderstanding. York ME: Stenhouse Publisher. In: Allen S. (2003). An analitic comparison of three models of reading strategy instruction. Internal Review of Applied Linguistics in Language Teaching (IRAL), 41(4), 319.

Keer, H. V. ve Verhaeghe J. P. (2005). Effects of explicit reading strategies instruction and peer tutoring on second and fifth graders' reading comrehension and self-efficiency perception. The Journal of Experimental Education, 73(4), 291-329.

Lin, M.S. (1999). The Effects of Creative Drama on Story Comprehension for Children In Taivan. Unpublished doctoral dissertation, Arizona State University, USA.

Lukenbill, W.B. (2004). Community Resources in the School Media Center: Concepts and Methods. Libraries unlimited. ISBN: 1-59158-110-9. LC. 2004048926. 195. chart. Diags. İllus. Bibliogs. Index. CIP. In: Pfeifer, Teresa (2005). Teaching reading strategies in the school library. School Library Journal, 51(6), 192.

MEB, (2006). Talim Terbiye Kurulu Başkanlığı Yeni İlköğretim Çalıştayı. 25-27, Ocak. Ankara.

Okay, O. (2004). Okumayan toplum. Türk Dili, 629, 411-424.

Okvuran, A. (2002). Çağdaş İnsanı Yaratmada Yaratıcı Drama Eğitiminin Önemi ve Empatik Beceri Empatik Eğilim Düzeylerine Etkisi. Aktaran: Adıgüzel. H.Ö. (2002). Yaratıcı drama/19851995/ yazılar. (1. cilt.). Naturel Kitap Yayınc1lık. Ankara.

Rhoder, C. (2002). Mindful reading: Strategy training that facilitates transfer. Journal of Adolescent and Adult Literacy, 45(6), 498.

San, İ. (2002a). Yaratıcı Drama - Eğitsel boyutları. Yaratıcı Drama/1985-1995/ Yazılar,1. Cilt. Ankara: Naturel Kitap Yayınc1lı.

San, İ. (2002b). Eğitimde Yaratıcı Drama. Yaratıcı Drama/1985-1995/ Yazılar. 1. Cilt. Ankara: Naturel Kitap Yayınc1lık.

San, İ. (1999). Türkiye'de Yaratıcı Drama Çalışmalarının Dünü ve Bugünü. Ankara: Ankara Üniversitesi Çocuk Kültürü Araştırma ve Uygulama Merkezi Yayınları 
Sarıhan, Z. (2003). Öğrencilere kitap okutmak için masrafsız bir proje: Okullarda her ay bir kitap. Yaşadıkça Eğitim. Ekim-Aralık, 31-34.

Schunk, H. ve Zimmerman, B. J. (1994). Self Regulation Of Learning And Performance. New Jersey, USA: LawrenceErlbaum Associates Publishers.

Senemoğlu, N. (2001). Gelişim Öğrenme ve Öğretim Kuramdan Uygulamaya. Ankara: Ethem Yayınc1lik.

Susar-Kırmızı. F. (2006). İlköğretim 4. sınıf Türkçe öğretiminde çoklu zeka kuramına dayalı işbirlikli ögrenme yönteminin erişi, tutumlar, öğrenme stratejileri ve çoklu zeka alanlarl üzerindeki etkileri. Yayınlanmamış doktora tezi, İzmir: Dokuz Eylül Üniversitesi.

Susar-Kırmızı, F. (2004). Okuma anlama stratejileri ve köy enstitülerinde okuma etkinlikleri. Yeniden Imece, 3.

Üstündağ, T. (2000). Yaratıcı Drama Öğretmeninin Günlüğü. Ankara: Pegem Yayınları.

Üstündağ, T. (2002). Temel Eğitimde Drama. Yaratıcı Drama/1985-1995/Yazılar. 1. Cilt. Ankara: Naturel Kitap Yayıncılık.

Vural, B. (2004). Öğretim Faaliyetlerinde Yöntem-Teknik Ve Etkinlikler. İstanbul: Hayat Yayıncılık.

[1] http://www.ncsd.k12.pa.us/pssa/Reading/rihnd20a.htm. Son Erişim Tarihi: 06.01.2006.

\section{EK-1}

\section{Araştırmanın Uygulama Aşamasında Kullanılan Bir Plan Örneği}

İlköğretim 4. Sınıf Türkçe Dersi "Uzaya Giden Uçurtma" Konusu Ders Planı -Dördüncü Oturum (Okuduğunu Anlama Stratejilerinin, Yaratıcı Drama Yöntemiyle İşlenmesi)

Yaş Grubu: 10 Yaş (4. Sinıf)

Tema:Yenilikler ve Gelişmeler

Konu:Uzaya Giden Uçurtma

Süre: 5 Ders Saati

Araçlar: Uçurtma, oyuncak uzay araçları, boya kalemleri, uzay kıyafetleri yapmak için örtüler, farklı giysiler.

Yöntem ve Teknikler: Yaratıı Drama Yöntemi; Doğaçlama, Bilinç Koridoru, Ayna Çalışması, Devinim Tiyatrosu.

\section{Kazanımlar}

1. Okuduğu bir metinden sorular çıkarma (söyleme/yazma, önerilenler arasından seçip işaretleme).

2. Metin ile ilgili sorulara metinle bağlantılı olarak yanıt verme (söyleme/yazma, önerilenler arasından seçip işaretleme).

3. Okuduğu bir metinde gerçek olanla hayal ürünü olanı ayırt edip söyleme/yazma (önerilenler arasından seçip işaretleme).

4. Okuduğu şiirin ana duygusunu söyleme/yazma (önerilenler arasından seçip işaretleme). 
5. Metinde verilen ipuçlarından hareketle, karşılaştığı yeni kelimelerin anlamlarını tahmin ederek söyleme/yazma (önerilenler arasından seçip işaretleme).

\section{Hazırlık-Isınma Aşaması}

1. Güçlü-zayıf oyunu oynanır. "Güçlü” denince vücut gerdirilir. Kollar yukarı açılır. "Zayıf” deyince vücut serbest bırakılır. Hareket sağa, sola, arkaya, öne vb. taraflara yapılarak tekrarlanır.

2. Hayali uzaylı oyunu oynanır. Gruptan birisi ortaya çıkar. Ortaya çıkan kişi uzaylıdır. Herkes Uzaylı arkadaşına hayali olarak bir şey giydirir ya da takar. Daha sonra bunların ne olduğu sırayla söylenir. Grupta bir ebe belirlenir. Ortaya gelen kişi teknolojik bir aletin şeklini oluşturur ve diğer arkadaşları bunun ne olduğunu tahmin etmeye çalışır.

3. Hayali uzay aracı oyunu: Gruptan bir uzay aracının parçaları olmaları istenir. İlk gelen kişi donarak durur. Diğerleri de sırayla gelir ve donarak arkadaşlarını tamamlar. Daha sonra herkes, uzay aracının hangi parçası olduğu söyler.

\section{Canlandırma Aşaması}

1. Daha önceden istenen uçurtma, oyuncak uzay araçları, boya kalemleri üzerinde konuşulur.

2. Şiirin başlığının söylenmesi ve "Başlık size ne çağrıştırıyor?” sorusunun yöneltilmesi. Çocukların şiirin resimlerini incelemesi, "Şiirin konusu ne olabilir? Tahminde bulununuz." sorusunun sorulması ve bu soru üzerinde konuşulması.

3. Şiirin çocuklar tarafından hızla gözden geçirilmesi, ilk ve son cümlelerinin ise dikkatle okunması ve metne yönelik olarak şu soruların sorulması:

Şiir neyle ilgilidir? Bu şiirden neler öğrenebilirsiniz?

4. Şiirin sessizce okutulması. Daha sonra şiirin sesli bir şekilde okutulması.

5. Bilinmeyen kelimelerin belirlenerek, anlamlarının tahmin edilmesi ve buna bağlı olarak sözlük kullanma çalışmalarının yapılması.

6. Sınıf 6’şar kişilik gruplara bölünür. Çocuklara şu yönerge verilir:

"Okuduğunuz şiirdeki çocuğun hayallerinden birisini canlandırınız."

7. Gruplara konuyla ilgili çalışma yaprağı verilir. Uzay Bilimleri Enstitüsünde çalışan bir bilim adamı olduğunuzu düşünün. Gizli bir görev olarak sizden bir uzay aracı yapmanız istendi. Nasıl bir araç yapmak isterdiniz? Grup arkadaşlarınızla birlikte uzay aracının resmini çiziniz (Çalışma Yaprağı 1).

8. Gruplara şu açıklama yapılır: "Yaptığınız uzay aracıyla uzaya gideceksiniz. Yanınıza yalnızca bir kişi almanıza izin verilmektedir. Yanınıza kimi alırsınız?” (Bilinç koridoru tekniği uygulanır).

9. Gruplara ayna tekniği uygulanır. Grup karşılıklı iki sıra olur. Aşağıdaki yönerge gruba söylenir.

"Uzaylılar sizce nasıl hareket ediyor olabilir. Sağ taraftakiler bu hareketleri yaparken karşısındaki öğrenciler aynisinı yapsin."

10. Sınıf 6 gruba bölünür. Gruplara yeni bir yönerge verilir: "Gemi mürettebatı ve yanınıza aldığınız kişiyle birlikte uzaylılarla karşılaşma anınızı canlandırınız."

11. Gruplara bir şarkı yazmaları için çalışma yaprakları dağıtılır: "Gemi mürettebatı ve uzaylıların birlikte söyleyebileceği bir şarkı yazın. Yazdığınız şarkıyı besteleyerek dans gösterisi şeklinde sununuz." (Çalışma Yaprağı 2).

12. Gruplara yeni bir yönerge verilir: "Uzaylılardan ayrılma anınızı ve dünyaya varışınızı canlandırınız."

\section{Değerlendirme-Tartışma}

Öğrenciler, canlandırdıkları uzaylılara ve yaptıkları uzay gemisine ilişkin olarak konuşturulur. Bir önceki etkinlikte oluşturulan gruplar yeniden bir araya getirilir. "Ĕger dünyamızda uzaylılarla birlikte yaşamak zorunda olsaydık hayatımız nasıl olurdu?" konusunda ortak bir rapor yazmaları istenir. 


\title{
Summary
}

\section{The Creative Drama Method in the Process of Reading Comprehension on Turkish Teaching and the Creative Drama Method About Students' Opinion}

\author{
Fatma SUSAR KIRMIZI. \\ Pamukkale University
}

\section{Introduction}

The reading, which is counted as the fundamental aim of knowledge gathering, is the elementary ways of knowledge gaining. In order for understanding what is read, make connections between what is read and one's own life, make a summary of the information, reach a consequences, create questions about the texts should be performed. Understanding the text depends on the effective usage of reading skills. Effective readers use these strategies professionally.

In order to perform meaningful reading, the students need a programmed strategy training. They should know where, when, how and why used which strategy. The method that make student enjoy and be active affects the usage of reading strategy and language training positively. Creative drama is one of those methods. Supporting the reading activities with creative drama enables the experienced the process, actively.

\section{Method}

The study was carried out in fourth grade students in a medium SES public elementary school in Bucaİzmir in the Spring semester of 2005- 2006 academic year. The treatment implemented on 37 (19 female, 18 male) students on the theme of "Innovations and Developments" and lasted five weeks.

For the instrument, a scale with three questions about reading process was developed. This scale was used as pre and post test. It aimed to determine what students know about reading strategies and whether they used these strategies. Furthermore at the end of the treatment, the students' opinion was gathered about creative drama activities which were carried out five weeks.

The study planned and carried out by the researcher lasted 25 lessons hours with five hours in a week. Treatment involves the elements of Turkish teaching a listening, speaking, reading, writing, visual 
reading, visual presentation. The daily lesson plans and worksheets were developed with this perspective whereas reading activities got special attention.

\section{Findings}

Before and after the treatment, the students were asked about what they did to understand better. Examining the pre-implementation responses showed that students have superficial knowledge about prior to reading, reading and after reading strategies. It can be said that they did not know and used most of the strategies. However the responses at the end of the treatment showed that this situation changed in dramatically.

At the end of the study, students were asked about their opinion on creative drama. Gathered responses showed that students developed positive thinking about both the method and the course.

\section{Conclusion and Discussion}

Supporting the reading activities with creative drama method enables experienced the process actively. "The knowledge gained through drama is not getting memorized knowledge in school discipline. In drama the knowledge gathered from different disciplines used however they were constructed with the unique objective and subjective connections (San, 2002b: s.69)".

The integration of method training and creative drama method enables that each student with their peers involves in the learning process actively, performed many activities like estimation about text, drawing the Picture of the story, writing poem related with main idea, analyzing the reasons and results of the text, improvisation of the text, preparing posters, creating still image.

In this study, creative drama based activities in reading strategies teaching in Turkish course were developed and implemented. According to classroom observations and participants' responses study has reached study's aims. Examining the responses showed that students' responses to pre reading, during reading and after reading displayed important developments. 
